Citation: Yümün, Z , Kam, E, Önce, M, Açıkgöz, G . "Stratigraphic and Geochemical Characteristics of Kulakçayiri Lake (Istanbul/Turkey) And Its Vicinity". Journal of Engineering Technology and Applied Sciences 1 (2) $2016: 69-75$

\title{
STRATIGRAPHIC AND GEOCHEMICAL CHARACTERISTICS OF KULAKÇAYIRI LAKE (ISTANBUL/TURKEY) AND ITS VICINITY
}

\author{
Zeki Ünal Yümüna ${ }^{a *}$, Erol Kam ${ }^{b}$, Melike Öncec, \\ Sevinç Yümün ${ }^{\mathfrak{c}}$ and Gülderen Açıgö̈z ${ }^{b}$ \\ $a^{*}$ Department of Environmental Engineering, Faculty of Çorlu Engineering, University of Namık \\ Kemal University, Çorlu/ Tekirdağ, Turkey \\ zyumun@nku.edu.tr \\ ${ }^{b}$ Department of Physics, Faculty of Arts and Sciences, University of Yıldiz Technical, Esenler/ \\ Istanbul, Turkey, \\ erolkam@yildiz.edu.tr, \\ ${ }^{c}$ Department of Enviromental, Institute of Science, Namık Kemal University, Çorlu/ Tekirdăg, Turkey \\ melike-once@hotmail.com,sevinc.yumun@gmail.com
}

\begin{abstract}
This study investigated the trace element potential of stratigraphic units in Kulakçayırı Lake and its vicinity, in Arnavutköy. In this context, trace element analysis was carried out using three drilling samples taken from Kulakçayırı Lake. In addition, grain size distribution analyses were performed to determine the lithological properties of the drilling samples in the stratigraphic sequence. At the base of the lake bed, there is a distribution of sediment consisting of clay from 3 to $6.5 \mathrm{~m}$ thick, and at deeper levels, clayey sand, or sandy clay.

In the analyses, nineteen separate elements and $\mathrm{CaO}, \mathrm{TiO} 2$ and $\mathrm{Fe} 2 \mathrm{O} 3$ concentrations were determined using X-ray spectrometry methods. Wavelength Dispersive X-Ray Fluorescence Spectrometry (WDXRF) was used for these measurements.

As a result of the elemental analysis, heavy metals including cobalt $(\mathrm{Co})$, nickel $(\mathrm{Ni})$, copper $(\mathrm{Cu})$, lead $(\mathrm{Pb})$, chromium $(\mathrm{Cr})$, and radioactive elements including uranium $(\mathrm{U})$ and thorium $(\mathrm{Th})$, were detected in the sediments. In addition, rare metals (lanthanum, cerium and neodymium) of the lanthanide group were also found. In particular, the elevation of the $\mathrm{Pb}$ concentration in the $\mathrm{BH}-1$ drilling location is remarkable. This height is due to the sediment structure around the natural lake.
\end{abstract}

Keywords: Arnavutköy Lakes, Kulakçayırı Lake, Lake Sedimentology, Stratigraphy, Kulakçayırı Geochemistrys. 


\section{Introduction}

In recent years, lake and sea sediment quality studies have become quite widespread. For ecological analysis, the lithology and element distribution in sediments is of utmost importance. As the Kulakçayırı Lake is due to be closed for the construction of Istanbul's third airport, this last evaluation of the data will be an important data source (Figure 1). This data will be the last representative data of the study area and will be a reference for future studies in the surrounding areas.

In this study, the inorganic geochemistry of the Kulakçayırı natural lake's sediments covering the current lake basin is investigated. In addition, grain size distribution analyses were performed to determine the lithological properties of the drilling samples in the stratigraphic sequence.

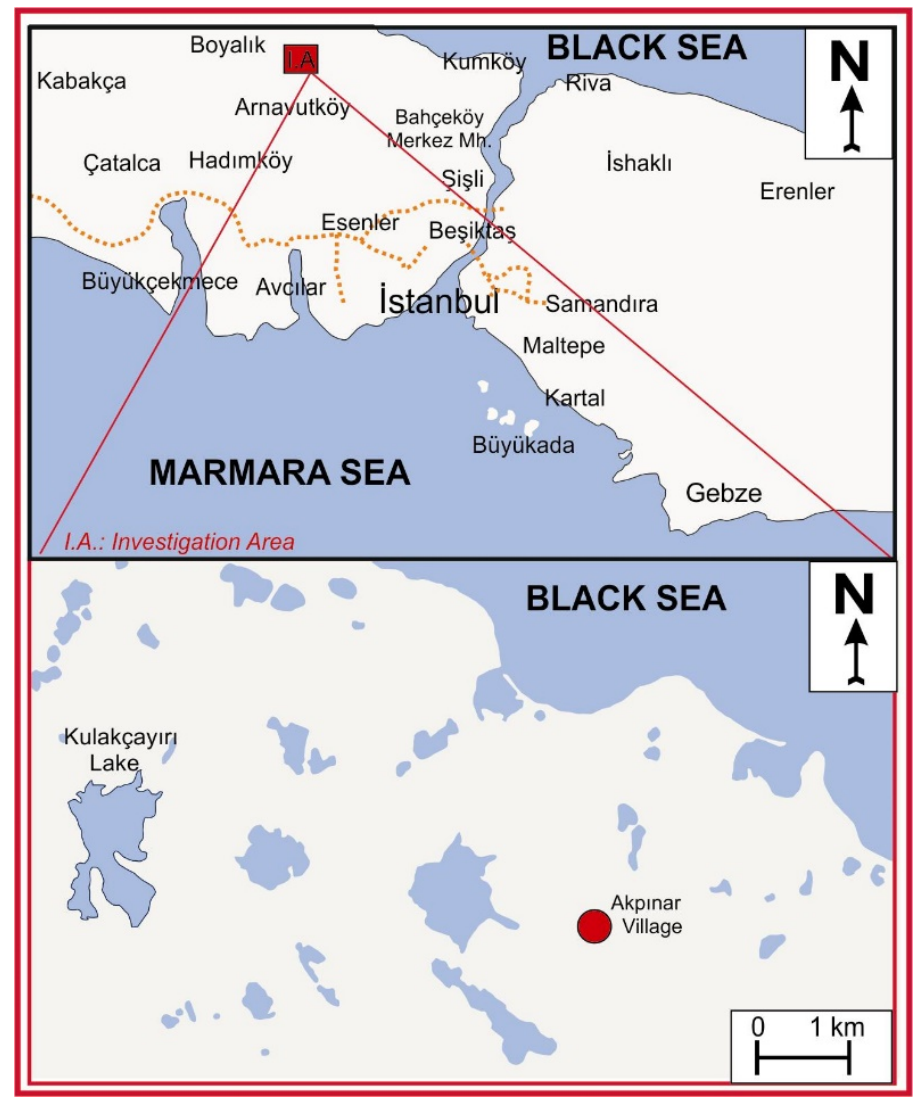

Figure 1. Location map of study area.

Contaminants from metals and other wastes are of special importance amongst other chemical pollutants because they can emerge from a wide variety of sources, constitute common causes of pollution, are resistant to environmental conditions, always have biological effects and can easily accumulate in increasing concentrations in living organisms entering the food chain [1, 2].

Some of the metals are transported in water depending on their solubility capacities, while others accumulate directly onto the lake basin sediments. Over time, the sediment layer becomes saturated with respect to its metal content, and it tends to return the ions it contains 
to the water mass again. In this case, the sediment layer at the bottom of the lake may become a potential source of pollutants for lake waters [3].

Therefore, knowing the geochemical structure of sediment is important to determine the source of contamination and to determine the presence of living organisms in the water ecosystem.

\section{Materials and method}

The study area is Kulakçayırı Lake, a shallow water source between two provinces of Istanbul: Arnavutköy and Hadımköy, and the Black Sea [4]. The study area location map is shown in Figure 1 and the study area drilling location map is shown in Figure 2. Coordinates for the drilling are given in Table 1.

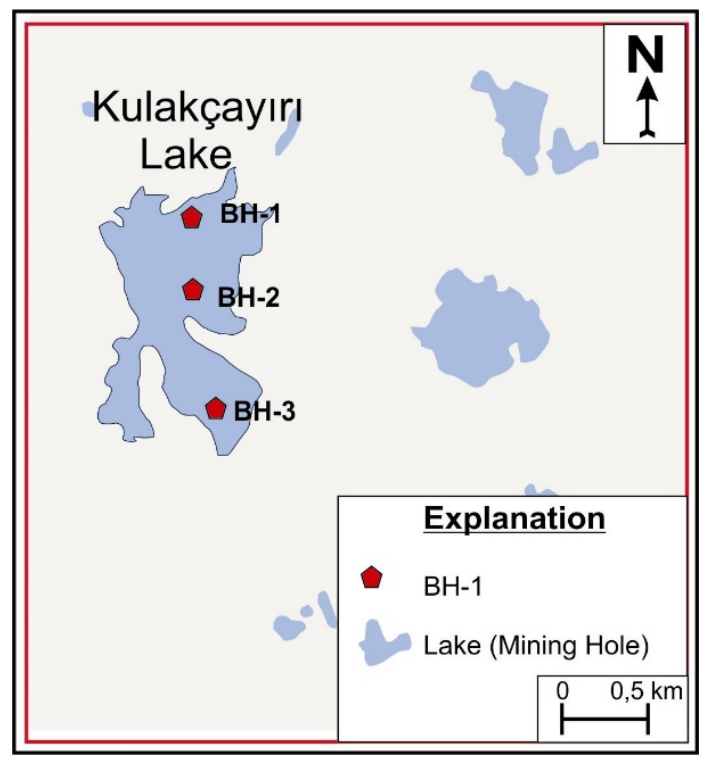

Figure 2. Study area drilling locations.

Table 1. Kulakçayırı Lake Drilling Coordinates.

\begin{tabular}{|c|c|c|c|}
\hline & BH & X & Y \\
\hline \multirow{2}{*}{$\begin{array}{c}\text { Kulakçayırı } \\
\text { Lake }\end{array}$} & BH-1 & 645459.77 & 4572767.77 \\
\cline { 2 - 4 } & BH-2 & 645529.00 & 4572399.00 \\
\cline { 2 - 4 } & BH-3 & 645511.81 & 4572001.24 \\
\hline
\end{tabular}

In this study, three core drilling samples were taken from the lake (Table 1). Elemental analyses of samples were carried out using X-ray spectrometry methods. Wavelength Dispersive X-Ray Fluorescence Spectrometry (WDXRF) was used for the measurements. Elemental analysis determines the substances in the structure of inorganic and organic substances found in solid, liquid or gas samples [5].

The system is equipped with end-window X-ray tubes with a $4 \mathrm{~kW}$ output and can be operated at $160 \mathrm{~mA}$ to give the highest sensitivity and lowest detection limits for light elements. The spectrometer is controlled by a 'SuperQ' software program. The spectrometer can be fitted 
with 7 crystals to separate the fluorescent wavelengths produced by the samples and transmitted by the collimator [6].

\section{Results}

The Thrace Formation (Undifferentiated), which is basically lower carboniferous, is located in the study area (Figure 3, 4).

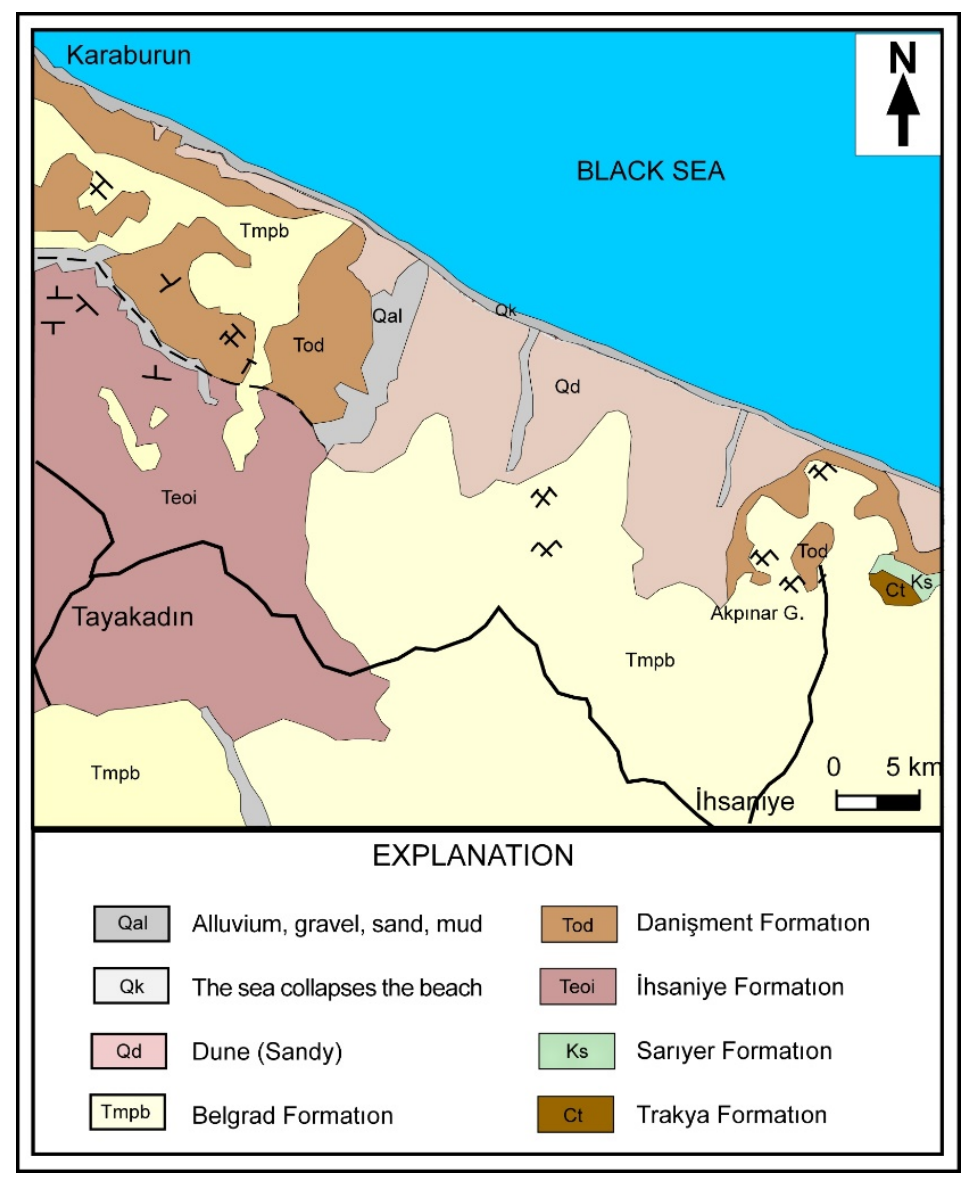

Figure 3: Geological map of the study area and its close vicinity.

The Upper Cretaceous (Campanian-Maastrichtian) aged Sariyer Formation unconformably overlies it. The unit consists of lavas, tuff and agglomera, intercalated marl, conglomerate and sandstone lithology. The Upper Eocene aged Ihsaniye Formation overlies the Sarlyer Formation with angular unconformity. 


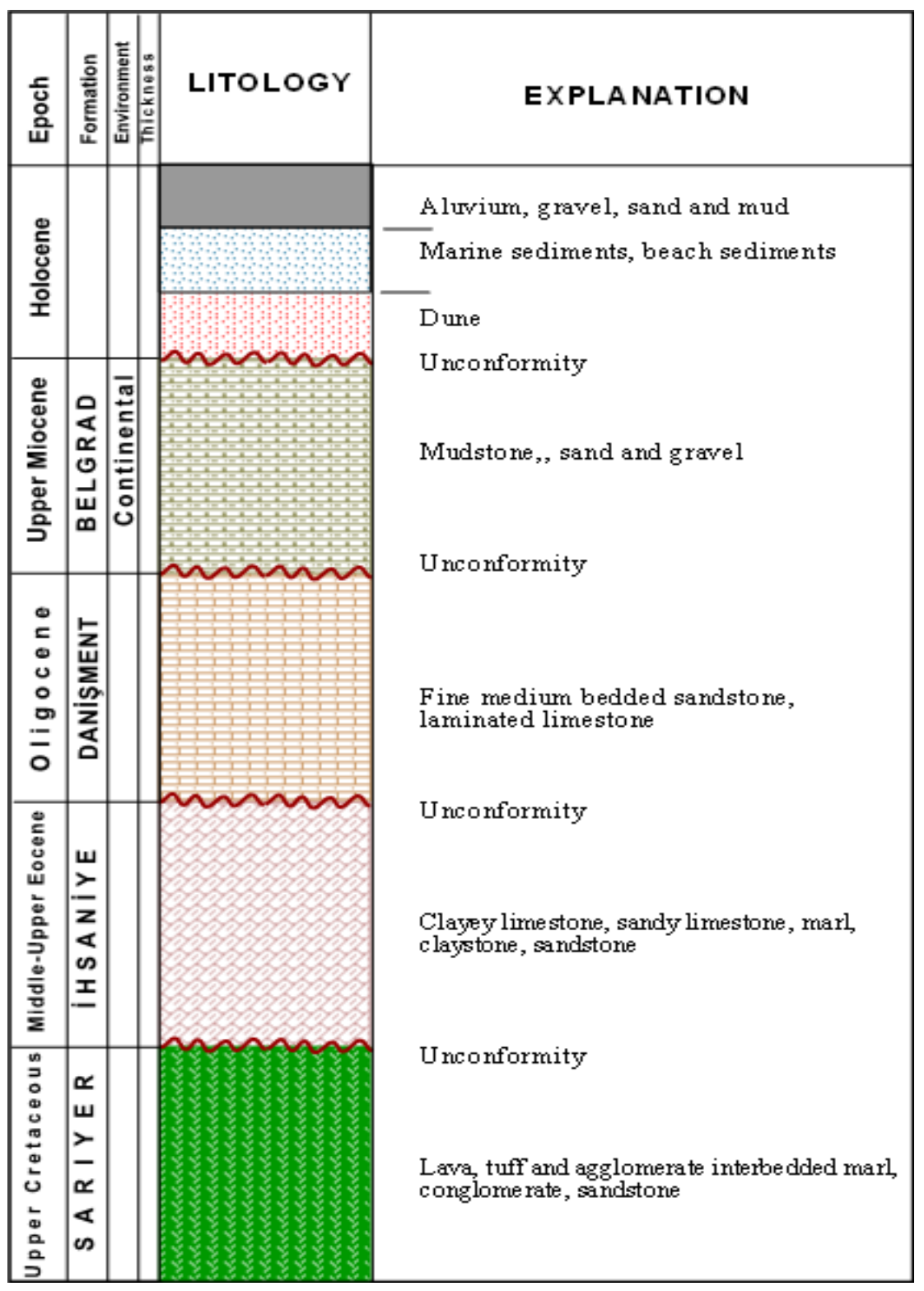

Figure 4: The Generalized Stratigraphic Colon Section of the Study Area and its Vicinity (Unscaled). The unit consists of clayey limestone, sandy limestone, marl, claystone and sandstone with intermediate level tuff. The Upper Oligocene aged Danişment Formation overlies this unit with an unconformable void. The Danişment formation consists of fine to medium bedded sandstone and laminated claystone alternation. This unit also has the Miocene-Pliocene aged Belgrad Formation. All of the basement units are covered with sand dunes in the plains close to the Black Sea coast, and the alluvium in the valley beds and flat areas cover all the units with angular incompatibility [7].

The elemental analysis results of the study area are given in Table 2. According to the analysis results, the most abundant elemental oxide is $\mathrm{Fe}_{2} \mathrm{O}_{3}$ for all three samples. The samples also show a rich structure in terms of carbonate mineral $(\mathrm{CaO})$. At the base of the lake there are clays with a thickness of 3 to $6.5 \mathrm{~m}$, clayey sand or sandy clay ground was found at deeper levels. The Eocene aged Ihsaniye Formation and Oligocene aged Danişment Formation were found at deeper levels. Units of claystone and sandstone lithology have been described as discrete sediments because of the high degree of dissociation [4]. 
Table 2. Elemental analysis results.

\begin{tabular}{|l|l|l|l|l|l|}
\hline \multicolumn{2}{|c|}{ BH 1 } & \multicolumn{2}{c|}{ BH 2 } & \multicolumn{2}{c|}{ BH 3 } \\
\hline $\mathbf{C a O}$ & 13879 & $\mathbf{C a O}$ & 10987 & $\mathbf{C a O}$ & 10708 \\
\hline $\mathbf{S c}$ & 12.11 & $\mathbf{S c}$ & 15.01 & $\mathbf{S c}$ & 13.40 \\
\hline $\mathbf{T i O} \mathbf{2}_{2}$ & 10119 & $\mathbf{T i O 2}$ & 11452 & $\mathbf{T i O 2}$ & 10873 \\
\hline $\mathbf{V}$ & 110.20 & $\mathbf{V}$ & 129.17 & $\mathbf{V}$ & 118.92 \\
\hline $\mathbf{C r}$ & 151.22 & $\mathbf{C r}$ & 169.30 & $\mathbf{C r}$ & 161.83 \\
\hline $\mathbf{M n}$ & 994 & $\mathbf{M n}$ & 403 & $\mathbf{M n}$ & 492 \\
\hline $\mathbf{F e} \mathbf{O}_{3}$ & 65742 & $\mathbf{F e 2 O 3}$ & 71936 & $\mathbf{F e 2 O 3}$ & 69281 \\
\hline $\mathbf{C o}$ & 30.93 & $\mathbf{C o}$ & 25.23 & $\mathbf{C o}$ & 29.58 \\
\hline $\mathbf{N i}$ & 91.33 & $\mathbf{N i}$ & 109.16 & $\mathbf{N i}$ & 104.87 \\
\hline $\mathbf{C u}$ & 38.91 & $\mathbf{C u}$ & 37.34 & $\mathbf{C u}$ & 37.00 \\
\hline $\mathbf{Z n}$ & 62.71 & $\mathbf{Z n}$ & 67.33 & $\mathbf{Z n}$ & 63.69 \\
\hline $\mathbf{R b}$ & 72.88 & $\mathbf{R b}$ & 76.21 & $\mathbf{R b}$ & 78.33 \\
\hline $\mathbf{S r}$ & 162.85 & $\mathbf{S r}$ & 155.94 & $\mathbf{S r}$ & 156.47 \\
\hline $\mathbf{Y}$ & 25.44 & $\mathbf{Y}$ & 26.19 & $\mathbf{Y}$ & 24.99 \\
\hline $\mathbf{Z r}$ & 205.28 & $\mathbf{Z r}$ & 184.42 & $\mathbf{Z r}$ & 177.40 \\
\hline $\mathbf{B a}$ & 292.85 & $\mathbf{B a}$ & 329.50 & $\mathbf{B a}$ & 282.38 \\
\hline $\mathbf{L a}$ & 40.26 & $\mathbf{L a}$ & 39.70 & $\mathbf{L a}$ & 34.69 \\
\hline $\mathbf{C e}$ & 75.95 & $\mathbf{C e}$ & 73.31 & $\mathbf{C e}$ & 67.34 \\
\hline $\mathbf{N d}$ & 28.21 & $\mathbf{N d}$ & 28.47 & $\mathbf{N d}$ & 23.07 \\
\hline $\mathbf{P b}$ & 173.26 & $\mathbf{P b}$ & 25.51 & $\mathbf{P b}$ & 72.14 \\
\hline $\mathbf{T h}$ & 13.13 & $\mathbf{T h}$ & 13.30 & $\mathbf{T h}$ & 12.84 \\
\hline $\mathbf{U}$ & 5.28 & $\mathbf{U}$ & 4.10 & $\mathbf{U}$ & 4.87 \\
\hline & & & & & \\
\hline
\end{tabular}

The soil classification of the samples is given in Table 3. $\mathrm{Ml}$ and $\mathrm{Cl}$ soil classes obtained as a result of sieve analyses are clay, silt and sand sediments. The heavy metal contents of some geological reference rocks are given in Table 4. As a result of comparing the results of the geochemical analysis to these reference values, it is shown that the environment matches the general average of the earth's crust.

Table 3. Index (Physical) Properties of the Samples taken from the Lake.

\begin{tabular}{|c|c|c|c|c|c|}
\hline \multicolumn{2}{|c|}{ BH } & BH-1 & BH-2 & BH-3 \\
\hline \multicolumn{2}{|c|}{ SAMPLE NO } & UD & UD & UD \\
\hline \multicolumn{2}{|c|}{ DERİNLIK } & $\begin{array}{c}8,40- \\
8,90\end{array}$ & $\begin{array}{c}7,50- \\
7,00\end{array}$ & $7,00-$ \\
\hline \multirow{2}{*}{ Elek Analizi } & $+\# 10$ & $\%$ & 2 & 0 & 0 \\
\cline { 2 - 6 } & $-\# 200$ & $\%$ & 78 & 76 & 82 \\
\hline \multirow{2}{*}{$\begin{array}{c}\text { Atterberg } \\
\text { Limitleri }\end{array}$} & LL & $\%$ & 46 & 44 & 48 \\
\cline { 2 - 6 } & PL & $\%$ & 30 & 22 & 21 \\
\cline { 2 - 6 } & PI & & 16 & 22 & 27 \\
\hline \multirow{2}{*}{$\begin{array}{c}\text { Zemin } \\
\text { Sinifi }\end{array}$} & TS 1500 & MI & CI & CI \\
\hline
\end{tabular}


The result of further evaluation corresponds to an environment between shale and sandstone, which in turn corresponds to the Belgrad Formation and its decomposition products. In future studies, if the environment presents different results, investigation of the existing pollutants will be necessary.

Table 4. Heavy metal contents of some geological reference rocks [8].

\begin{tabular}{|c|c|c|c|c|c|c|c|c|}
\hline & $\begin{array}{l}\mathrm{Fe} \\
\%\end{array}$ & $\begin{array}{l}\mathrm{Mn} \\
\mathrm{ppm}\end{array}$ & $\begin{array}{l}\text { Co } \\
\text { ppm }\end{array}$ & $\begin{array}{l}\mathrm{Ni} \\
\mathrm{ppm}\end{array}$ & $\begin{array}{l}\mathrm{Cu} \\
\mathrm{ppm}\end{array}$ & $\begin{array}{l}\mathrm{Zn} \\
\mathrm{ppm}\end{array}$ & $\begin{array}{l}\mathrm{Pb} \\
\mathrm{ppm}\end{array}$ & $\begin{array}{l}\text { As } \\
\text { ppm }\end{array}$ \\
\hline $\begin{array}{l}\text { Earth crust (Mason and } \\
\text { Moore, 1982) }\end{array}$ & 5 & 950 & 25 & 75 & 55 & 70 & 13 & 1,8 \\
\hline $\begin{array}{l}\text { Shale (Turekian and } \\
\text { Wedepohl, 1961; Krauskoph, } \\
\text { 1985) }\end{array}$ & 4,7 & 850 & 19 & 70 & 45 & 95 & 20 & 13 \\
\hline $\begin{array}{l}\text { Sandstone (Turekian and } \\
\text { Wedepohl, 1961) }\end{array}$ & 0,9 & 50 & $<1$ & 2 & 5 & 16 & 7 & 1 \\
\hline $\begin{array}{l}\text { Limestone (Turekian and } \\
\text { Wedepohl, 1961; Şahinci, } \\
\text { 1991) }\end{array}$ & 0,4 & 1100 & $<1$ & 20 & 4 & 20 & 9 & 1 \\
\hline Ultrabasic (Aslaner, 1973) & 5,7 & $\begin{array}{l}700- \\
2600 \\
\end{array}$ & $\begin{array}{l}75- \\
101 \\
\end{array}$ & $\begin{array}{l}1700- \\
2900 \\
\end{array}$ & $\begin{array}{l}42- \\
62 \\
\end{array}$ & & & \\
\hline $\begin{array}{l}\text { Basalt (Krauskoph, 1985; } \\
\text { Şahinci 1991) }\end{array}$ & 8,6 & 1500 & 48 & & & & & \\
\hline
\end{tabular}

\section{References}

[1] Ceylan, S. Şanlı, Y., "Çevreve besin kirlenmesi”. Food Science Technology Journal , 3, (1-2) (1980): 76-92. [In Turkish].

[2] Klassen, C.D., Amdur, M.O.. Doull,, JToxicology (3th Ed. Macmillan Publishing Company, Nevvyork, USA, 1986).

[3] Şener, Şehnaz, and Erhan Şener, "Kovada Gölü (Isparta) Dip Sedimanlarında Ağır Metal Dağılımı ve Kirliliğinin Değerlendirilmesi." Süleyman Demirel Üniversitesi Fen Bilimleri Enstitüsü Dergisi 19.2 (2015): 49-58.

[4] Yümün Mühendislik Limited CompanyGeological. "Geotechnical Investigation of Istanbul Third Airport Lakes" (2013) (Unpublished).

[5] http://grumlab.giresun.edu.tr/index.php?id=312 (2016).

[6] http://www.speciation.net/Database/Instruments/PANalytical-BV/AxiosAdvanced;i1654 (2016).

[7] Kam, Erol, "Gamma Dose Rate Values In The Kulakçayiri Natural Lake And The Vicinity (Arnavutköy, İstanbul).” (2016): 27-32.

[8] Şener, Şehnaz, "Eğirdir göl suyu ve dip sedimanlarının hidrojeokimyasal incelemesi." (PhD diss. SDÜ Graduate School of Natural And Applied Sciences, 2010). 